\title{
Unusual development of sandur sedimentary succession, an example from the Pleistocene of S Poland
}

\author{
Tomasz Salamon ${ }^{1}$, Tomasz Zieliński ${ }^{2}$ \\ ${ }^{1}$ Department of Earth Sciences, University of Silesia, Będzińska Str. 60, 41-200 Sosnowiec, Poland; \\ e-mail: tomasz.salamon@us.edu.pl \\ ${ }^{2}$ Institute of Geology, Adam Mickiewicz University, Maków Polnych Str. 16, 61-606 Poznań, Poland; \\ e-mail: zielu@amu.edu.pl
}

\begin{abstract}
An atypical lithological development of outwash deposits in the Carpathians Foreland (S Poland) shows lower and middle parts of the sedimentary succession that are characterized by sinuous palaeochannels. This channel facies consists of laterally accreted sands derived from side bars. The sedimentary environment was a proglacial system of anabranching channels, presumably of anastomosed type. The outwash channel pattern was most probably controlled by the raising base level of the fluvial system. Both proglacial and extraglacial waters were dammed by a sandur within a small upland valley. Aggradation and progradation of the glaciofluvial deposits resulted in progressive rising of the dammed lake level. The low hydraulic gradient of the outwash streams resulted in a sinuous planform as well as a lowenergy style of deposition. Afterwards, the rising lake water was drained off through a low watershed and the entire valley became filled with outwash sediments. The bedrock morphology thus became buried and a typical unconfined sandur with a braided channel network developed during the last phase of the glaciomarginal sedimentation (upper part of the sedimentary succession under study).
\end{abstract}

Keywords: outwash deposits, sedimentology, Pleistocene, Poland

\section{Introduction}

Sandurs (outwash plains) are, as a rule, recognized as sedimentary environments dominated by typically braided rivers. This was already expressed in the early sixties of the last century, when Krigström (1962) published the first sedimentological study of Icelandic sandur plains. Later benchmark works (among others: Church, 1972; Klimek, 1972; Boothroyd \& Ashley, 1975; Rust, 1975; Boothroyd \& Nummedal, 1978; Bluck, 1979; Dawson \& Bryant, 1987; Fra- ser, 1993; Marren, 2005) worked this out into a depositional model: the sandur is nowadays the best example of a braided fluvial system. The extensive development of the typical braided channels on sandurs is controlled by the following factors: a highly unstable hydrologic regime regulated by glacier melting, a large flow and sediment discharge during floods, and cohesionless channel banks that are highly susceptible to erosion. Sheetflows are a secondary depositional factor for sandurs. The significance of sheetflows increases espe- 


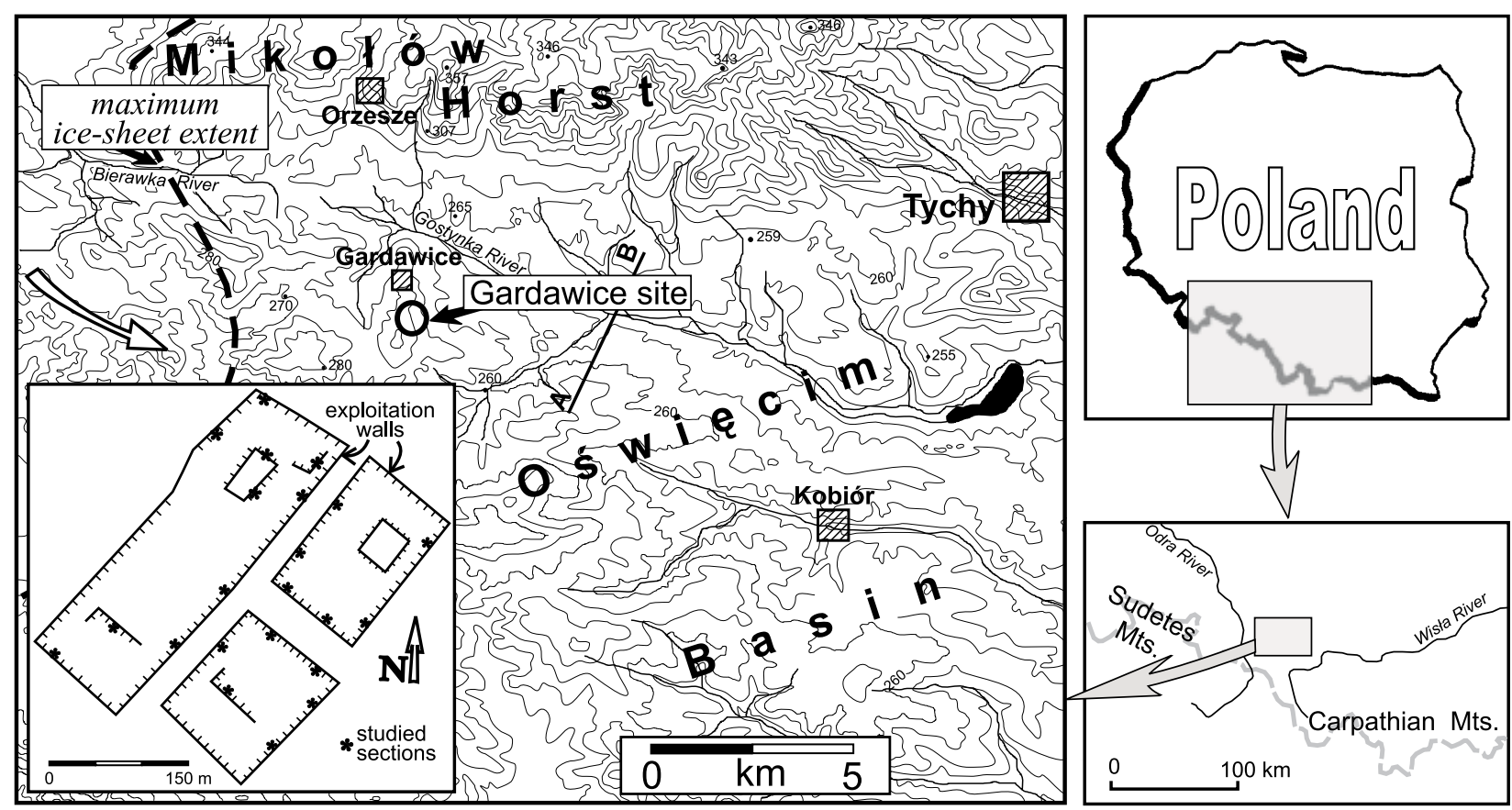

Fig. 1. Location map and detailed sketch of the studied site. Direction of ice-sheet advance is indicated by white arrow. Line A-B is the position of the geological cross-section shown in Figure 2.

cially in the distal parts of outwashes (cf. Krigström, 1962; Olsen \& Andreasen, 1995; Aitken, 1998; Zieliński \& Van Loon, 2003).

Since the pioneer study of Leopold \& Wolman (1957), meandering rivers are usually considered as opposite to braided streams. These two sedimentary environments are distinctly different with respect to fluvial geomorphology, style of deposition, and hydrological conditions. Therefore meandering rivers are, as a rule, not present on sandurs, but a few studies deal with such an exceptional situation: Klimek (1972) mentioned that meandering channels are formed on Icelandic outwash plains of extremely low slope $\left(3.1 \times 10^{-6}\right.$ $<\mathrm{S}<4.5 \times 10^{-6}$ ). This was characterized more precisely by Boothroyd \& Ashley (1975) and Boothroyd \& Nummedal (1978): in the distal, flat, vegetated zones of Alaskan sandurs, high-sinuosity channels are present. Point bars and side bars are abundant forms within these channels, whereas typical floodplain sedimentation takes place beside them.

Unusually developed outwash deposits have been found in the northern part of the Oświęcim Basin in southern Poland. Sedimentological analysis pointed out that these deposits accumulated not only in braided channel systems but also in sinuous, deep channels. In the first phase of outwash development, sinuous channels dominated the proglacial river system. Up to present, no similar sedimentary successions have been described from elsewhere. Therefore, the Polish succession is interesting and its interpretation is novel. The purpose of the present study is to reconstruct the precise palaeoenvironmental situation in which the sandur developed a sedimentary character that is quite different from the currently acknowledged models.

The succession under study has been described earlier by Salamon (2009) as an example of a relationship between the style of proglacial sedimentation and the morphology of the upland bedrock. The present contribution focuses on a more detailed sedimentological analysis, and contains new data which are the basis for a discussion about fluvial environment and sandur development under conditions of a changing base level.

\section{Study area}

The Gardawice site under study consists of a set of large sandpits in the northern part of 


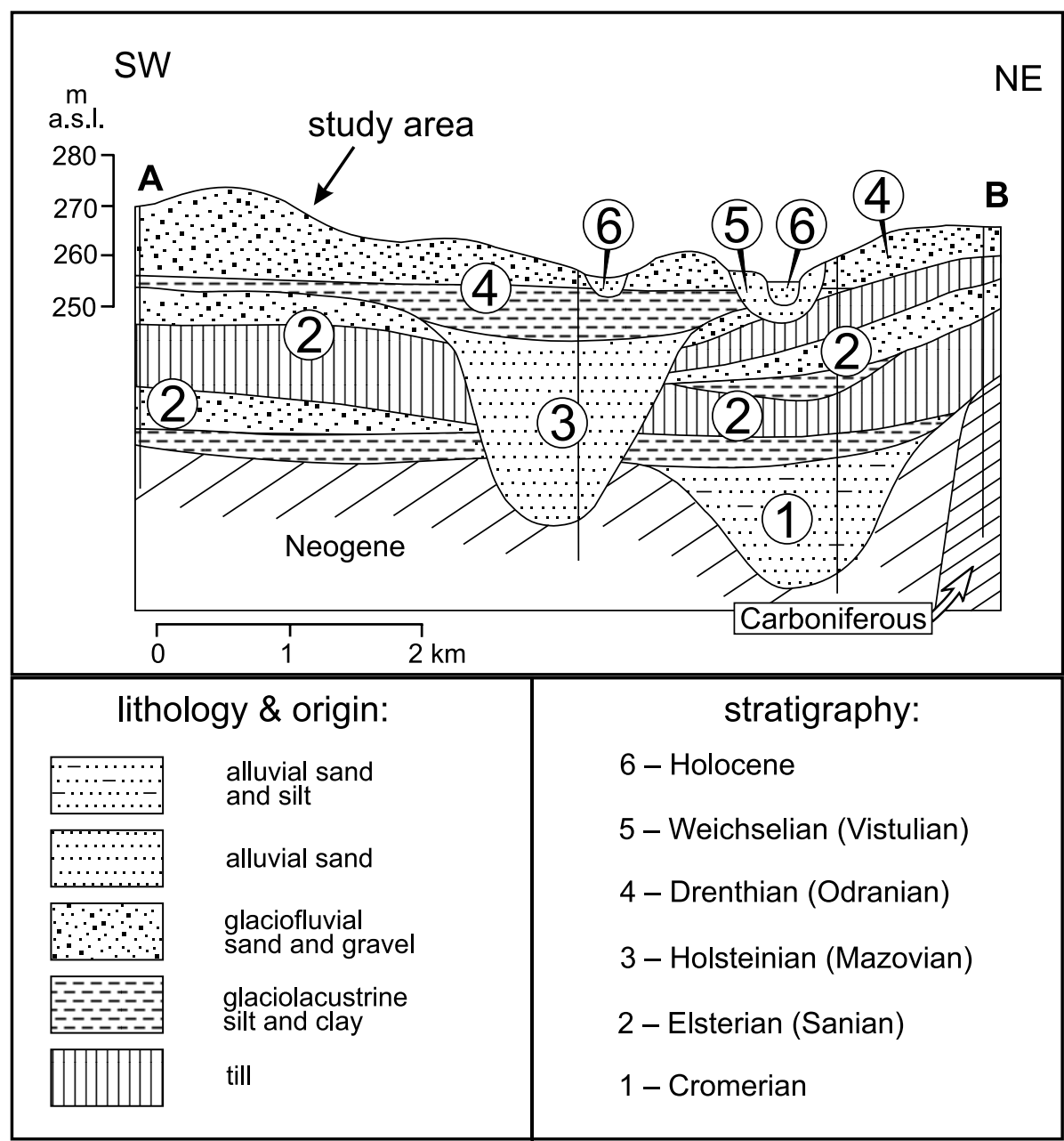

Fig. 2. Synthetic geological cross-section through the northern part of the Oświęcim Basin (based on Salamon \& Wilanowski, 2003). For location, see Figure 1.

the Oświęcim Basin in the Carpathians Foreland, southern Poland (Fig. 1). It is located in the watershed zone of the two largest Polish rivers: the Odra and the Wisła. The area around Gardawice is slightly undulating. The surface reaches $280-285 \mathrm{~m}$ a.s.l. and is gently inclined to the East. The Oświeccim Basin forms part of the Carpathian Foredeep and is filled with Neogene deposits, mainly clays. In the North, the Oświęcim Basin meets the Mikołów Horst, which belongs to the Silesian Upland (Kotlicka \& Kotlicki, 1979) built of Carboniferous rocks. The thickness of the Pleistocene deposits in the study area is $40-60 \mathrm{~m}$. They are represented by tills intercalated by sands, gravels and silts (the Elsterian complex) (Fig. 2) (Haisig \& Wilanowski, 1999). A sandy series of interglacial palaeovalleys is present as well (Klimek \& Starkel, 1972; Kotlicka \& Kotlicki, 1979; Haisig
\& Wilanowski, 1999). Glaciofluvial sands of Drenthian age form a surficial cover of the study area (Fig. 2).

Gardawice is located about $4 \mathrm{~km}$ from the line indicating the maximum extent of the Drenthian (Odranian in Polish stratigraphy) ice sheet (Karaś-Brzozowska, 1963; Lewandowski, 1982). Its position is marked by an extensive till cover west of Gardawice. The ice sheet advanced to this part of the Oświęcim Basin from the NW (Fig. 1). A large outwash plain then developed towards the ESE. It is important to mention here that, during the Drenthe Glaciation, the Wisła/Odra watershed was located more eastwards than nowadays (Lewandowski, 1996).

The ice sheet advanced into the upper part of the Bierawka drainage basin, where it formed a glaciomarginal lake. The 5-10 $\mathrm{m}$ thick succes- 
sion of gray clays and silts found in drill-holes (Haisig \& Wilanowski, 1999) (Fig. 2) represents this ice-dammed lake. Glaciolacustrine deposits underlie the outwash plain under study (Fig. 2). The contact between glaciolacustrine and glaciofluvial facies is at an altitude of 260 $\mathrm{m}$ a.s.l.

\section{Description of the sandur succession and its interpretation}

The exposed sandur succession is $10-20 \mathrm{~m}$ thick and is mainly composed of sands. Four glaciofluvial units have been distinguished at the Gardawice site. The lowermost unit contains several lithofacies associations. Each upper unit corresponds with a single lithofacies association. The lithofacies associations that build up the various units are denoted by code symbols (Table 1 ) of the most frequent beds.

Table 1. Lithofacies code symbols used in text and figures (partly modified after Miall, 1978).

\begin{tabular}{cl}
\hline \multicolumn{2}{c}{ Textural symbols } \\
\hline$F$ & silt \\
$S$ & sand \\
$S F$ & silty sand \\
$S G$ & gravelly sand \\
\hline \multicolumn{2}{c}{ Structural symbols } \\
\hline$i$ & large-scale inclined cross-stratification \\
$l$ & low-angle cross-stratification \\
$p$ & tabular cross-stratification \\
$t$ & trough cross-stratification \\
$r$ & ripple cross-lamination \\
\hline$w$ & wavy lamination \\
\hline
\end{tabular}

\section{Unit 1}

\section{Description}

Unit 1 shows both vertically and horizontally significant differences in lithology but few lithofacies associations are present (Fig. 3). The most common is a relatively fine-grained association $S h,(S r, S F w)$. It is dominated by fine-grained, horizontally stratified sands, $S h$.
This lithofacies is intercalated by sand beds with various types of ripple lamination $S r$ (including climbing ripples), as well as silty sands with wavy lamination SFw (Fig. 4). The most fine-grained (silty and sandy/silty) deposits form often sheet-like packages with a large horizontal extent, at least several tens of metres. Sometimes the sand beds are arranged in palaeochannel structures of 1.5-2.0 $\mathrm{m}$ deep and 20-30 m wide.

Another characteristic association, $S i$, is abundant in the lower unit. It is formed by large-scale (2-4 m thick) sets of fine-grained sand laminae (Fig. 3). Parallel laminae are inclined at angles of $10-20^{\circ}$. Lithofacies $\mathrm{Si}$ infills asymmetric palaeochannels which are a few metres deep and 20-60 m wide (Fig. 5). Cross-beddings indicate variations in current directions of up to $40^{\circ}$ within individual palaeochannels, whereas the current directions measured in adjacent palaeochannels are strongly different. Small- or medium-scale cross-stratification of intrasets within Si packages display an opposite orientation to the inclined beds (Figs. 6, 7). These intrasets are less common, but sometimes form sand beds of a few decimetres thick with trough $(S t)$ or planar cross-stratification $(S p)$. It is also characteristic that relatively thick beds of dune $(S t)$ cosets pass in the up-slope direction into rippled beds (Sr) (Fig. 8).

Lithofacies association $S t$ is composed of medium-grained sand. The sets with trough cross-stratification are up to $25 \mathrm{~cm}$ thick (Fig. 8 ). They form cosets $0.7-1.5 \mathrm{~m}$ thick and several dozens of metres wide. The cosets are commonly characterized by a thinning-up tendency. The frequency of this association is evidently lower than that of the two associations mentioned earlier.

\section{Interpretation}

The main lithofacies association $S h,(S r$, $S F w)$ of this unit is typical of a low-energy fluvial environment. Horizontally stratified fine-grained sands $(S h)$ derived from shallow currents under upper plane-bed conditions. Rippled sand beds were formed by currents with a lower velocity. The large variability of ripple structures points to common discrete 


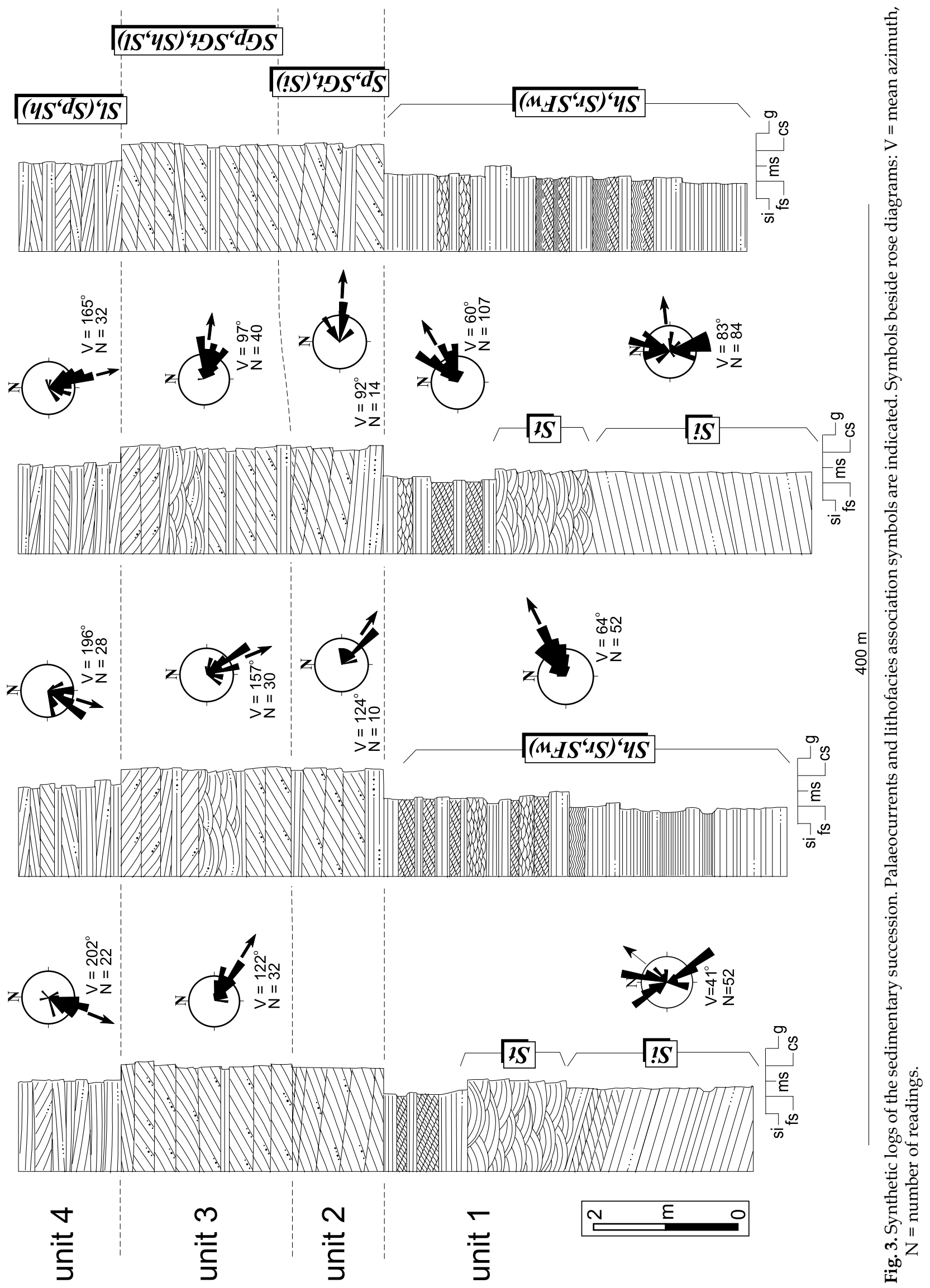




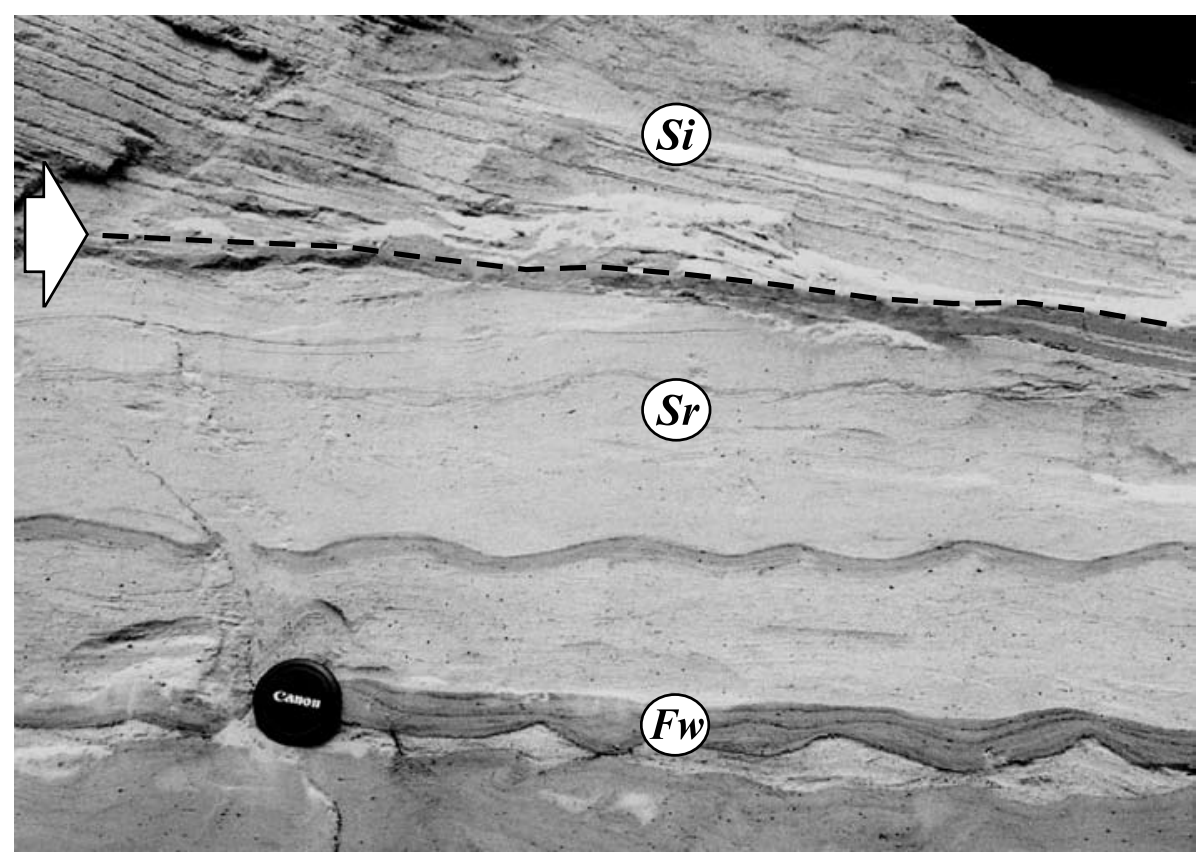

Fig. 4. Contact between two associations of unit 1 (see arrow). The lower association contains fine-grained rippled sand $(\mathrm{Sr})$ with silt intercalations $(\mathrm{Fw}$ ) derived from low-energy deposition in an abandoned channel. The upper one represents inclined sand beds $(\mathrm{Si})$ of side-bar origin.
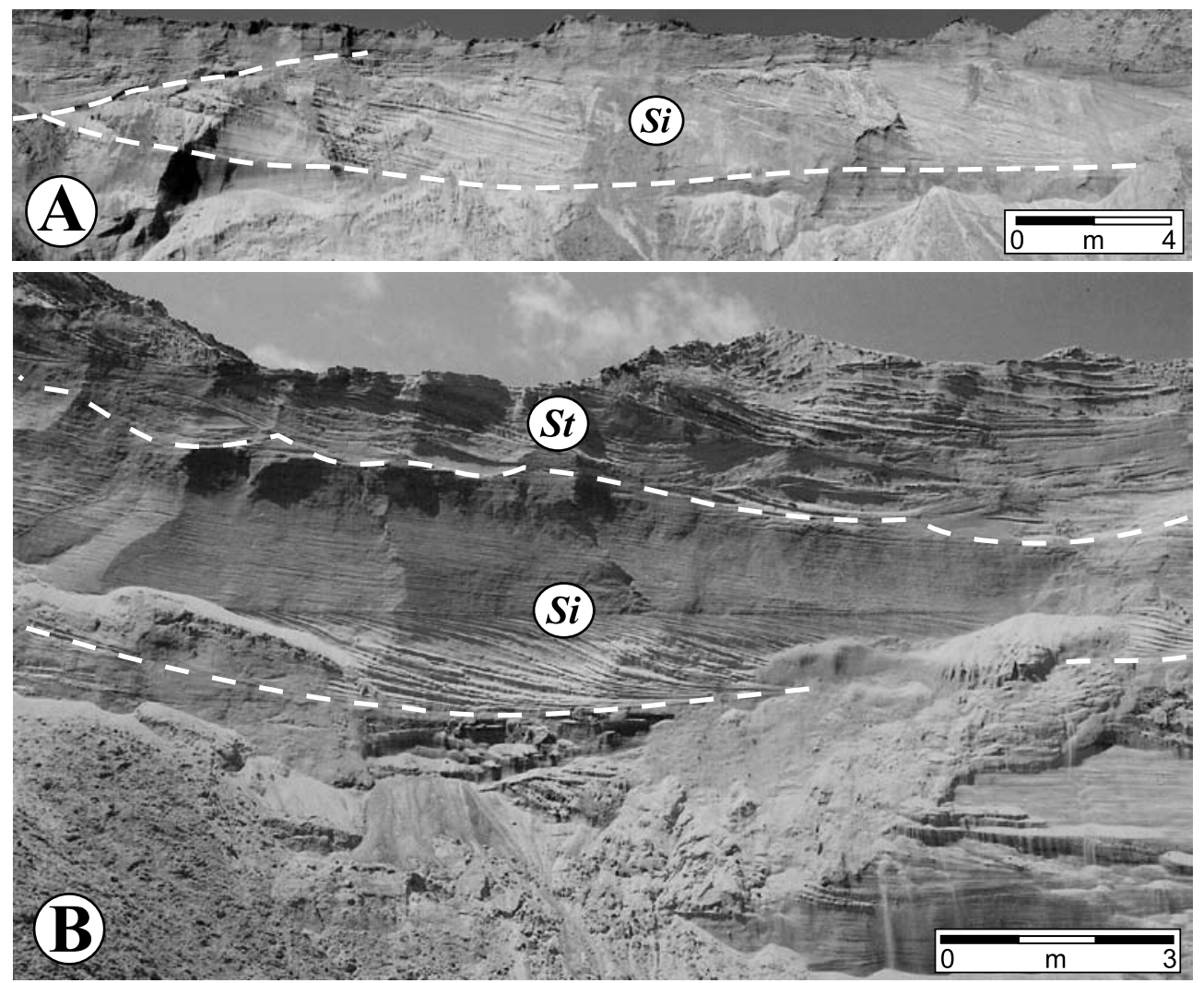

Fig. 5. Two examples of palaeochannels from unit 1.

A - Palaeochannel filled with a thick sandy package derived from a side bar; B - Two stacked palaeochannel infills. The lower infill was deposited by laterally accreted side bars (Si) and the upper one by 3-D dunes (St). 


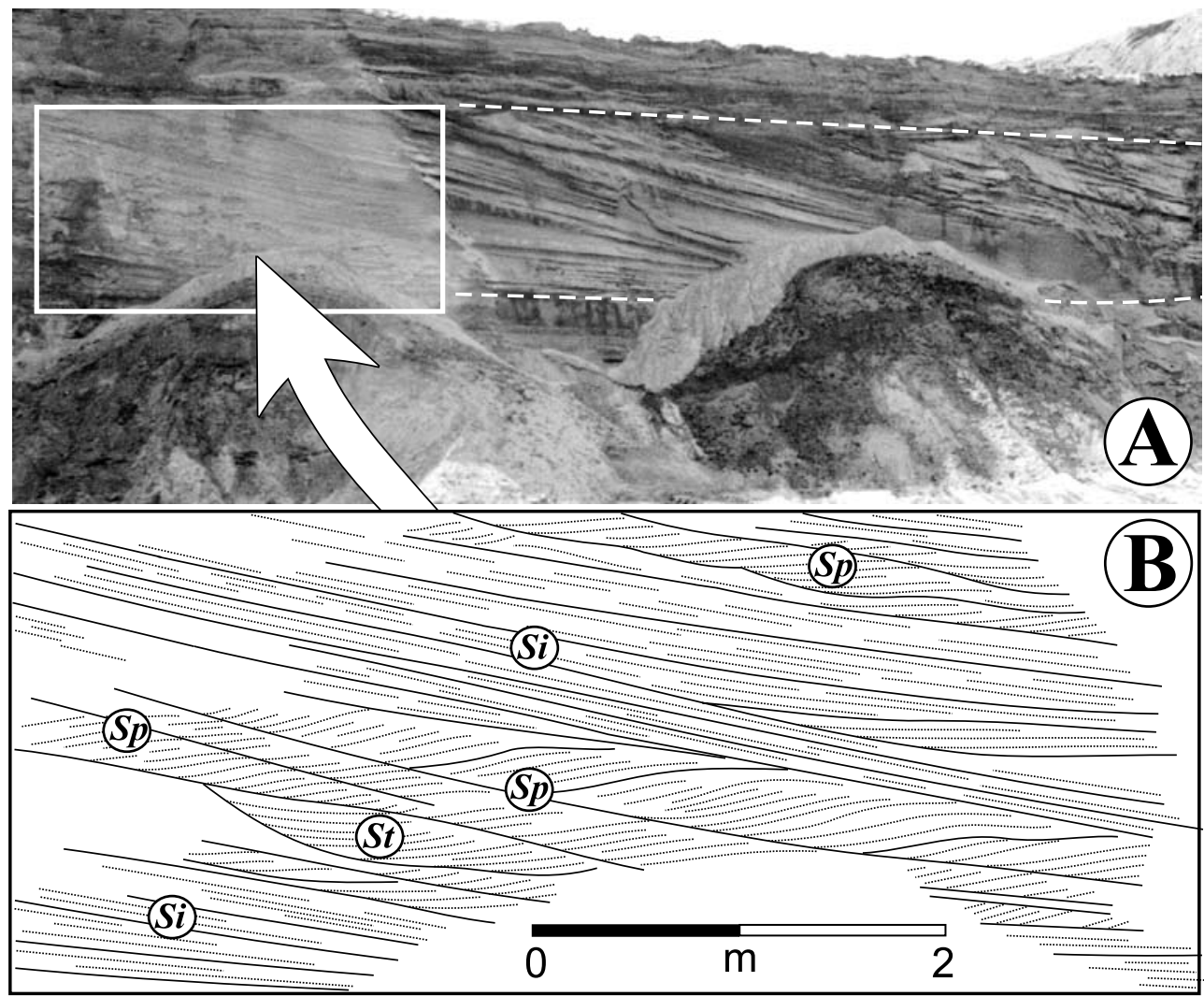

Fig. 6. Unit 1.

A - Palaeochannel filled with sand with large-scale inclined stratification (Si); B - Detailed sketch. Inclined layers are sandwiched with planar $(S p)$ and trough $(S t)$ cross-beds climbing on the slope of a side bar.

hydrodynamic fluctuations. Frequent conditions of nearly standing water are recorded in the silty sands with wavy lamination and the fine sands with climbing-ripple structures. The low energy level of this fluvial environment is also confirmed by the only occasional presence of the dune-derived $S t$ lithofacies. We interpret this association therefore as a deposit of a lowenergy, shallow, sand-bed alluvial channel of low sinuosity, with a discharge dominated by relatively small amounts of water. A quite similar lithological character of braided-like river alluvium has been documented from the Carboniferous of Ireland (Graham, 1981) and the Pleistocene of Poland (Krzyszkowski, 1991). Additionally, similar fluvial records have been identified by Fraser \& Cobb (1982), Dawson \& Bryant (1987) and Zieliński \& Van Loon (2003) from the distal parts of sandurs.

The considerable thickness of sands with inclined stratification $(\mathrm{Si})$ is evidence that this association was deposited in a distinctly deep $(2-4 \mathrm{~m})$ current. The small dip angle of the laminae (evidently smaller than the angle-ofrepose of foresets) contradicts microdeltas and large-scale transverse bars as the parent depositional forms. In our opinion, lithofacies $S i$ can be identified as a record of side bars accumulated in a sinuous channel. These bar forms were located nearby the inner banks of river bends, which is evidenced by the progressive change of the dip direction of foreset laminae within each $S i$ sand body, as well as by the presence of parasitic bedforms climbing up the bar form slopes (Figs. 6, 7, 8). This deposit is similar to some successions of inner bank bars of meandering rivers (Allen, 1965; Singh, 1977; Smith, 1987; Makaske \& Nap, 1995). Lithofacies Si has also been commonly noted in classical packages of epsilon cross-stratification, although together with abundant cross-bedded sands and thin silty intercalations (Gradziński, 1970; Doktor \& Gradziński, 1985; Gibling \& Rust, 1987). The limited width of these bodies suggests that lateral migration of channels was not extensive. 


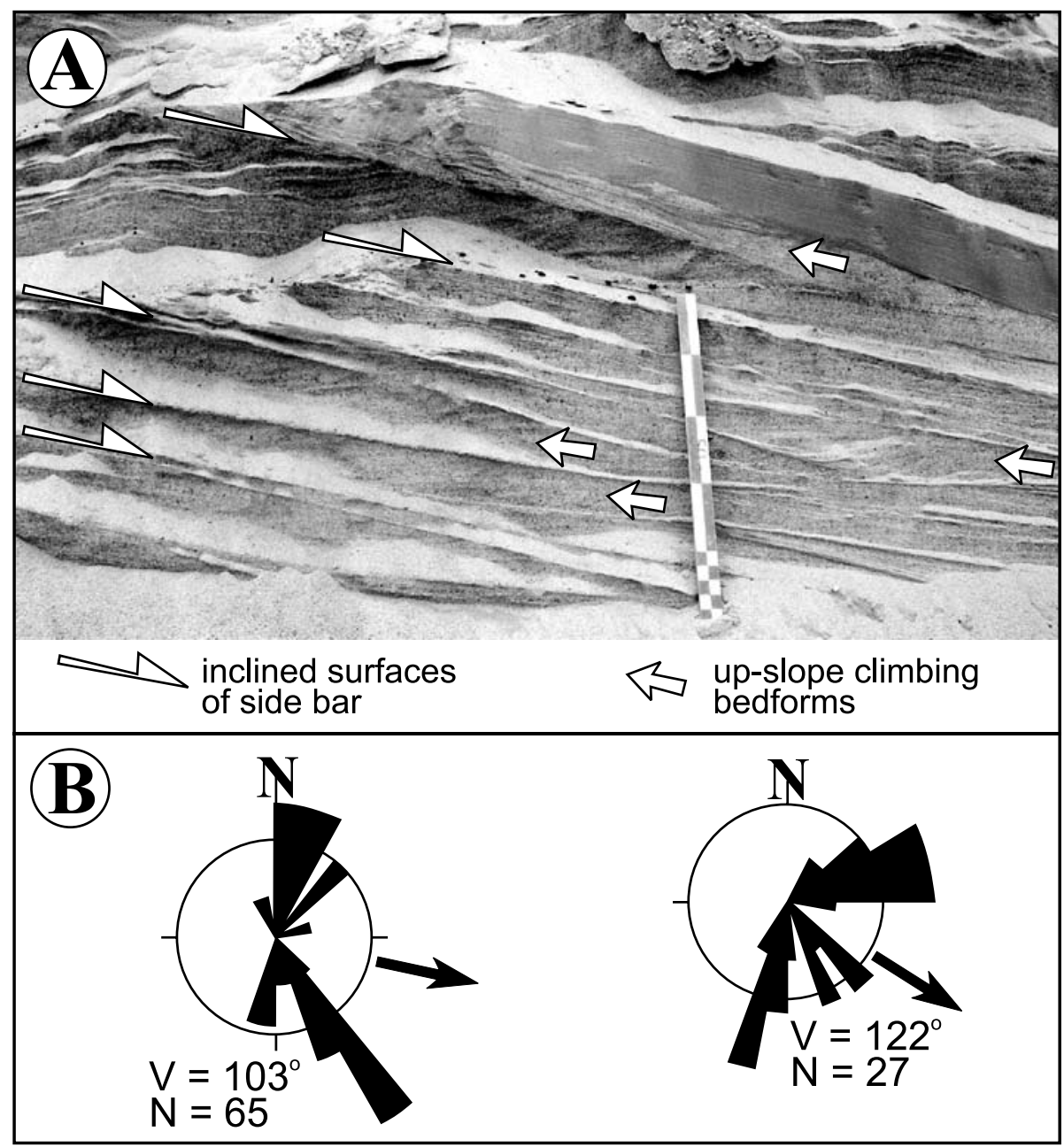

Fig. 7. Lithofacies association Si of series 1.

A - Sandy succession of point-bar origin. The scale is $0.5 \mathrm{~m}$; B - Directional distribution of the point-bar facies. Each pair of highly spread modes represents inclined beds of the bar slope and cross-laminations of parasitic climbing ripples. $\mathrm{V}=$ mean azimuth, $\mathrm{N}=$ number of readings.

To summarize, the deposits of the lower unit seem to represent a fluvial system with anabranching, sand-bed, bedload-type channels. Alluvial channels are represented as two types: the few main channels - association $\mathrm{Si}$ - were deep, sinuous and displayed limited lateral migration, whereas the network of secondary channels of low sinuosity - association $S h,(S r, S F w)$ - was denser but the streams were nearly two times shallower, as well as narrower and quieter than those of the first type. In its entity, this environment can be regarded as a low-energy fluvial system representing the distal zone of an outwash plain. There are some premises that the outwash streams formed an anastomosed-like pattern. The sandur fits with its interpretation as an anabranching channel system with low-energy discharges. The moderate sinuosity of the palaeochannels corresponds with the morphology of most anastomosing rivers (see McCarthy et al., 1991; Teisseyre, 1992; Smith et al., 1997; Makaske, 1998). The estimated depth of the first-rank palaeochannels is in agreement with the observations of McCarthy et al. (1991) and Smith et al. (1997). The width-to-depth ratio of the first-rank palaeochannels ranges from 10 to 20 . This value is in agreement with the data of anastomosing river ribbons (Törnqvist et al., 1993; Shuster \& Steidtmann, 1987; Kirschbaum \& McCabe, 1992). The upper plane bed and alternating side bars are common depositional forms in anastomosing channels (Rust \& Legun, 1983; Wende \& Nanson, 1998; 


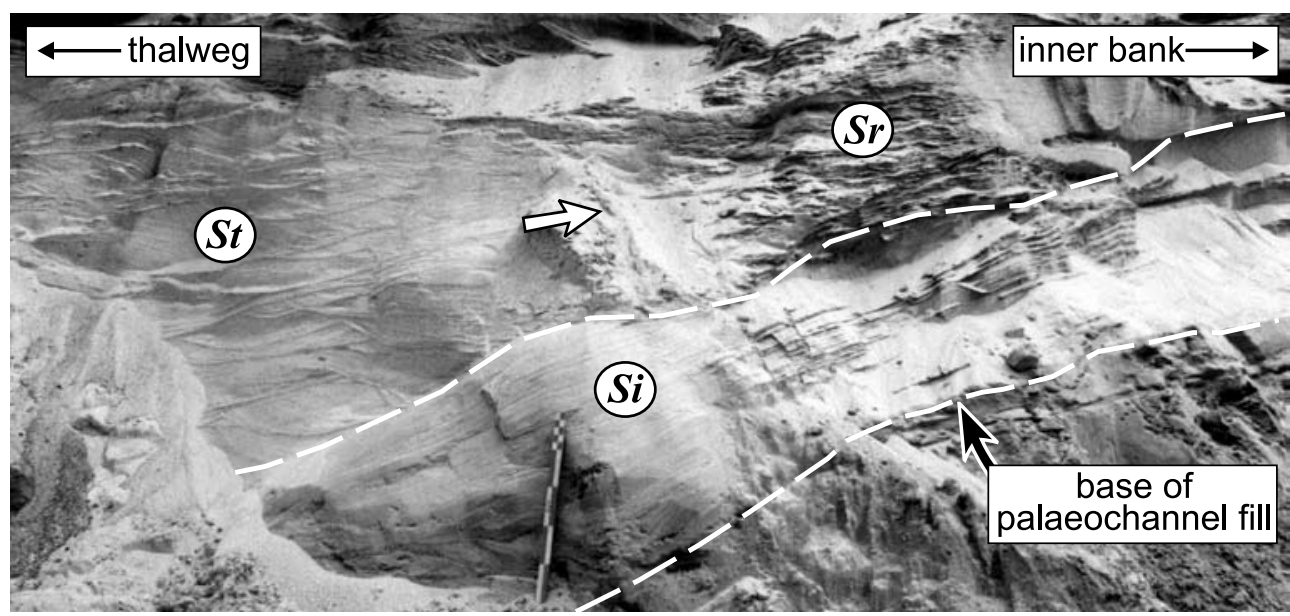

Fig. 8. Characteristic lateral passage of lithofacies filling the palaeochannel (unit 1, association Si). 3-D dunes (St lithofacies) climb on the slope of a point bar (see arrow) and change into ripples (Sr) in the near-bank zone of a weaker current. The scale is $0.5 \mathrm{~m}$.

Tooth \& Nanson, 1999). The grain size of these deposits (fine to coarse sand) is also similar to that of alluvium from anastomosing rivers (McCarthy et al., 1991; Smith et al., 1997). The presence of two facies - the main and the secondary channels - obviously adds weight to this environmental interpretation (cf. Smith, 1983; Gibling et al., 1998). The lithological characteristics of the lower unit suggest that the Pleistocene fluvial system was transitional between the two types of anabranching rivers distinguished by Nanson \& Knighton (1996): the sand-dominated, island-forming river and the mixed-load, laterally active river. Both of them were identified by Makaske (2001) as true anastomosing rivers.

A basic question emerges: what did control the development of such an atypical pattern of the sandur fluvial system? In our opinion, the complex nature of the outwash river resulted from the meltwaters that fell into an extraglacial lake located in a relatively small valley. This westwards sloping valley was dammed by the outwash plain that accumulated in front of the ice-sheet margin. The lake was surrounded by elevated areas, so that the sediment and meltwater supply resulted in a progressive baselevel rise. This phenomenon controlled the decreasing slope of the sandur channels. Such low-energy currents formed an anabranching river pattern where some sinuous channels were dominated by the lateral accretion of side bars.

\section{Unit 2}

\section{Description}

This unit is more coarse-grained than the lower one. Coarse sand and gravelly sand beds with planar cross-stratification $(S p)$ and trough cross-stratification (SGt) dominate (Fig. 3). Cross-beds are $10-50 \mathrm{~cm}$ thick. These lithofacies frequently exist in cosets, which are inclined at angles of several degrees. It is characteristic that cross-laminae usually dip opposite to the cosets (Fig. 9). These inclined cosets form packages which extend for 10-20 m. Their thickness is $1.2-1.8 \mathrm{~m}$. The sporadically cross-stratified lithofacies are accompanied by sets of coarse sand (Si), but their thickness and lateral extent is much less than in unit 1 . In some zones, $S p$ and SGt beds are not inclined, but in subhorizontal position. In these cases, subordinate lithofacies of horizontally stratified sand (Sh) co-exist. Measurements of cross-stratification indicate that the laminae dip most commonly towards a sector from SE to W.

\section{Interpretation}

In a previous study (Salamon 2009), our units 2 and 3 were considered as one unit. New field data and their interpretation indicate, however, that they should rather be dealt with as separate units because of a different lithology and different sedimentary conditions. The coarser texture of the deposits reflects a higher energy of the river system than in 

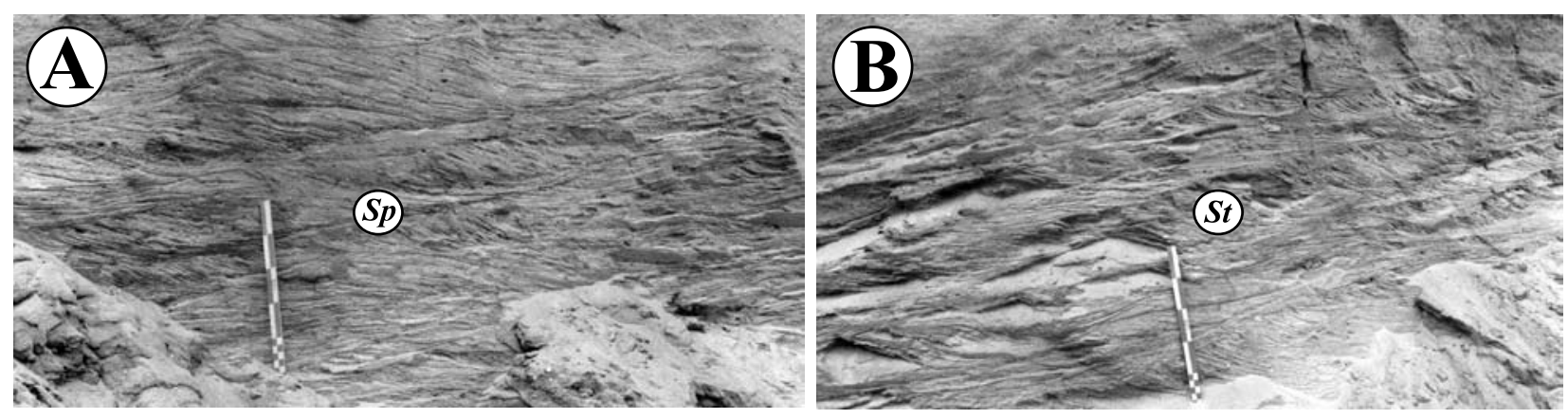

Fig. 9. Unit 2.

A - Inclined beds (right side) contain large-scale cross-stratification oriented in opposite directions. Facies of a side bar located in a strongly curved bend. The scale is $0.5 \mathrm{~m}$; B - The upper part of the side-bar succession is dominated by small-scale cross-beds climbing towards the inner bank of the bend. The scale is $0.5 \mathrm{~m}$.

unit 1. The thick $S p$ lithofacies reflect central foreset bars in channel shoals. Such bars are commonly characterized by straight segments of the alluvial channels with extensive bedload transport and deposition (Bristow, 1993; Santos \& Stevaux, 2000; Lunt et al., 2004). The $S G t$ cosets represent 3-D dunes formed in the deeper parts of these channels. It is important to discuss here the presence of the inclined beds with an $S p$ and St lithofacies (Fig. 9). These beds with climbing cosets are interpreted as laterally accreted side bars in bends of the streams, where deposition was controlled by secondary transverse currents. The limited lateral extent of the inclined cosets suggests that lateral migration of the channels was insignificant. In our opinion, the alluvial system of unit 2 was characterized by transitional channels of moderate sinuosity. Deposition was controlled both by the central, foreset bars in the straight segments and by the side bars in bends. The depth of the main channels was up to $1.5-2.0 \mathrm{~m}$. Similar fluvial systems have been described from both present-day and ancient environments (Smith, 1970; Rust, 1978; Ferguson, 1987; Bridge et al., 1998; Bridge \& Lunt, 2006).

\section{Unit 3}

\section{Description}

This unit is $3.5-5 \mathrm{~m}$ thick and contains gravelly sand and coarse sand. Lithofacies association $S G p, S G t,(S h, S l)$ is characterized by a small lateral variability (Fig. 3). In contrast to both lower units, all beds are in horizontal position. Gravelly sand with planar crossstratification (SGp), in sets up to $0.5 \mathrm{~m}$ thick, dominates. The SGp lithofacies forms mostly thick cosets. These packages pass laterally into sandy-gravelly cosets of trough cross-stratification $(S G t)$. Lithofacies of secondary importance in this association are horizontally stratified sand $(S h)$ and sand with low-angle cross-stratification $(\mathrm{Sl})$. Horizontally stratified gravel and fine-grained rippled sand beds are quite rare. The uppermost part of the association contains a few fine-grained beds. Massive silt $(F m)$ forms lenses up to $1 \mathrm{~m}$ thick and up to several tens of metres long.

The foresets of cross-beds dip mostly towards the SE (Fig. 3).

\section{Interpretation}

The lithological features of unit 3 point out that these are deposits of a braided river with extensive bar deposition. The dominating lithofacies $S G p$ represent central foreset bars formed on shoals during falling stages. The lithofacies SGt represent sinuous dunes in deep thalweg zones. Lithofacies $S l$ and $S h$ on top of $S G p$ facies are interpreted as lowrelief, washed-out dunes $(S l)$ and upper-stage plane-bed deposits (Sh) which were formed on bar platforms during final phases of waning floods. Both the presence of depositional units formed under near-critical conditions and the limited thickness of cross-beds points out that the alluvial channels were relatively shallow (approx. $1 \mathrm{~m}$ ) with locally deeper thalweg zones. Lithofacies association SGp, SGt, (Sh, 
Sl) can be identified as a deposit accumulated in the middle sandur (cf. Fraser \& Cobb, 1982; Dawson \& Bryant, 1987; Olsen \& Andreasen, 1995). The silty Fm beds are attributed to abandoned channels during periods when the activity of the outwash streams was temporarily interrupted.

We conclude that this part of the sedimentary succession corresponds to the fluvial environment with the highest energy during the entire evolution of the sandur under study.

\section{Unit 4}

\section{Description}

The upper unit is thin $(1.5 \mathrm{~m})$ and relatively fine-grained (mostly medium sand; gravelly sand is of secondary importance). The contact with the underlying unit 3 is gradational. Poor sorting is characteristic. The beds are thinner than in unit 3, with thicknesses up to $30 \mathrm{~cm}$. Sand beds with low-angle cross-stratification $(S l)$ are most frequent. Sands with tabular cross-stratification $(S p)$ and horizontal stratification (Sh) play a secondary role. Shallow sandy sets of trough cross-stratification $(S t)$ are sporadic. Rippled sand beds $(S r)$ are rare, too. These lithofacies jointly form an association $S l$, (Sp, Sh) (Fig. 3). The cross-bedding indicates a palaeocurrent towards the South.

\section{Interpretation}

These alluvial deposits also represent the environment of a characteristic braided river. Thin, poorly sorted sand beds are the result of low-relief sandwaves (lithofacies $S l$ and coexisting shallow troughs $S t)$, small foreset bars $(S p)$ and upper plane-bed deposits $(S h)$. They were all formed in shallow channels by fluctuating, fast currents. The sinuosity of the channels was likely low, which is supported by the lack of structures derived from lateral accretion.

The finer grain size and the lower frequency of trough cross-beds than in unit 3 is evidence that the braided river system had been slightly changed. Presumably the meltwater discharges were lower, what resulted in a reduction of the stream power and bed shear stress, as well as in a smaller depth of the channels.

\section{Palaeogeography of the glaciomarginal zone}

The succession of the four units reveals the evolution of the proglacial river system when the ice sheet had become stagnant at its maximum extent and during its first phase of recession. As Salamon (2009) stated, the channelpattern transformation was stimulated by the extraglacial morphology, which determined the changes of the outwash base level. The following phases of palaeogeographic development have been reconstructed for the study area.

During the first phase, a glaciomarginal lake was dammed by the ice-sheet margin in the Bierawka valley (Fig. 10A). Its largest extent was presumably simultaneous with the maximum glacial extent. Extensive sandur accumulation caused gradual shifting of the western shoreline towards the East, to the upper reach of the valley. The terminoglacial lake thus evolved into a proglacial one (Fig. 10B). A large sediment supply by meltwaters led to basin filling while the water supply was also still large. Both factors resulted in a permanent rise of the lake level so that conditions of positive accommodation space were reached. The lake shore was then presumably located 2-4 $\mathrm{km}$ from the site under study. Because of this relatively short distance, the outwash fluvial system could be controlled by the base-level factor. Aggradation of the sandur's distal part led to a progressive decrease of the slope of depositional surface, which was the main factor controlling the evolution of the fluvial system to an anastomosing-like pattern. This phase is recorded in outwash unit 1 .

The second phase started when the eastwards shifting lake reached the level of the relatively low watershed of the Bierawka valley (Fig. 10C). The dammed water began to overflow in an eastward direction into neighbouring valleys and the lake area probably became smaller. The drainage made an end to the water-level rise. The condition of a stable base level resulted in zero accommodation space. The outwash plain therefore started to adapt to a new longitudinal profile, steeper than the 


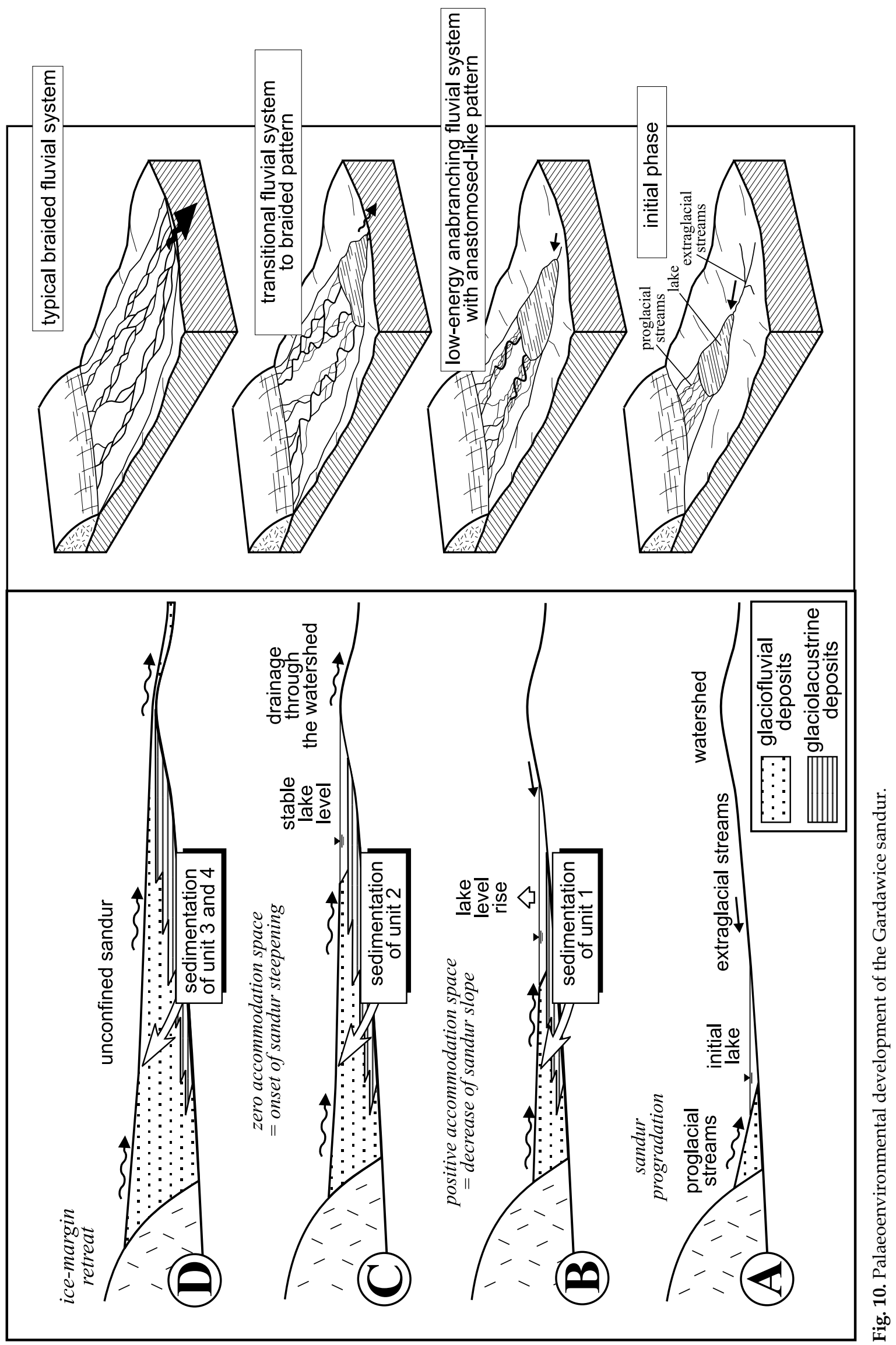


previous one. The zone of sandur aggradation moved from its distal part (during the first phase) to the proximal part. The increasing energy of the fluvial system gave rise to its metamorphosis into a transitional pattern. Sandur unit 2 is attributed to this development. The second phase of the palaeogeographic development can be regarded as the onset of the contemporary formation of a river network in the area.

Finally, the sandur accumulation filled in the whole valley (Fig. 10D). Concurrently, proglacial streams started to flow freely eastwards. In this way a typical braided river system developed (sedimentation of unit 3 ).

The last phase of outwash evolution was likely related with the initial retreat of the icesheet margin. The outwash facies retrogradated then towards the $\mathrm{W}$ and NW. The uppermost outwash unit 4 thus represents the environment of a braided river system, although with a lower energy level, as indicated by the finer deposits than in unit 3. The proglacial current was changed to a more southward direction (Fig. 3), what may be a response to the burying of all local watersheds under a glaciofluvial cover while the sandur fluvial system became fully unconfined.

\section{Evolution of the fluvial system}

The sedimentological features of the sandur succession suggest characteristic tendencies of an evolving fluvial system (Table 2). In the first phase of sandur evolution, an increase in channel sinuosity is inferred. The sinuous pattern of the main channels favoured the formation of side bars, which are recorded in lithosomes tens of metres wide (Fig. 11A). During the next phases, the sandur channels became progressively less and less sinuous. In the second phase (accumulation of unit 2) side-bar-derived sediments accreted laterally (perpendicular to the channel axis) at distances of 10-20 m only (Fig. 11B). The depositional style of unit 3 consisted exclusively of sedimentation of central bars, which suggests a quite low sinuosity of the sandur channels (Fig. 11C).
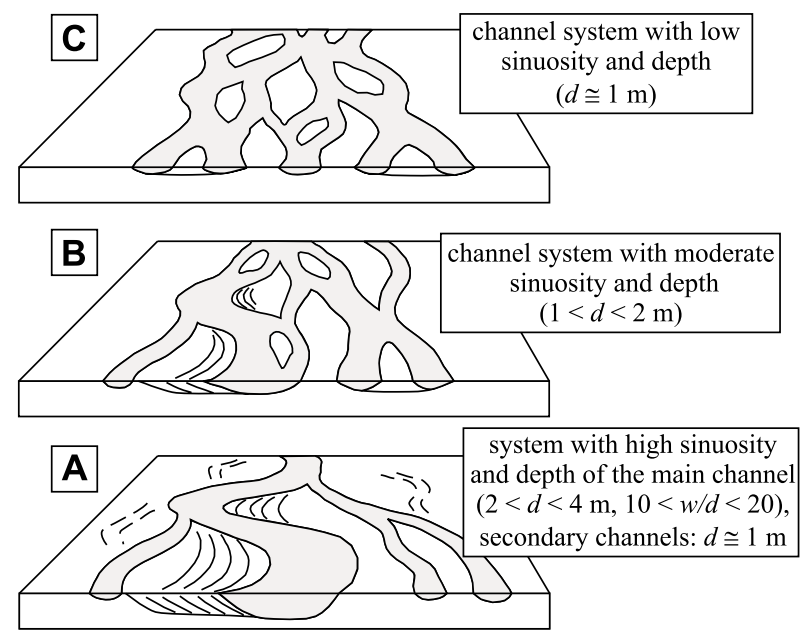

Fig. 11. Evolution of the channel pattern during the successive phases of sandur development.

Simultaneously with the changes in channel sinuosity, the depth of the proglacial current varied. The thickness of side-bar packages within the main channel facies of unit 1, indicates a 2-4 $\mathrm{m}$ depth. In unit 2, a significantly lower depth (1-2 $\mathrm{m}$ ) has been reconstructed for the packages of analogous bar origin. Finally, the depth of the palaeochannels of unit 3 decreased to approx. 0.5-1 m.

The differentiation of the palaeochannel depth implies that, during the first phase (sedimentation of unit 1), the fluvial system was composed of two types of channels: main and secondary ones. The main channels were large, i.e. deep and wide. In contrast, the secondary channels were at least two times shallower and narrower. They were characterized by extensive aggradation and the time-span of their activity was short. The shallow secondary channels did not display lateral migration, whereas they underwent most likely frequent avulsion. The differences of channel size within the fluvial system became progressively smaller during the successive younger phases of sandur evolution. The palaeochannels of units 3 and 4 were quite similar in depth and width, what means that the difference between main and secondary channels disappeared. This is typical of shallow, extensively aggrading, sand-bed braided rivers. Their alluvia can be subdivided into two basic facies only: foreset bars and interbar channels (cf. Olsen \& Andreasen, 1995; Wysota et al., 1996; Perez-Arlucea et al., 2000). 
Table 2. Evolution of the Gardawice sandur: main governing agents and reaction of the fluvial system.

\begin{tabular}{|c|c|c|c|}
\hline Trigger & Reaction & Fluvial geomorphology & Environment \\
\hline $\begin{array}{l}\text { deglaciation - initial retreat } \\
\text { of ice-sheet margin; } \\
\text { retrogradation of meltwa- } \\
\text { ter and sediment supply } \\
\text { zone }\end{array}$ & $\begin{array}{l}\text { stable sandur slope } \\
\text { (sediment transition and } \\
\text { reduced aggradation ratio); } \\
\text { decrease of meltwater } \\
\text { discharge; } \\
\text { slightly decreasing flow } \\
\text { energy; } \\
\text { accumulation of unit } 4\end{array}$ & $\begin{array}{l}\text { sandy upper plane bed and } \\
\text { washed-out bars in shal- } \\
\text { low channels of very low } \\
\text { sinuosity }\end{array}$ & $\begin{array}{l}\text { middle sandur zone } \\
\text { conditioned by decreasing } \\
\text { discharges; } \\
\text { sand-bed, shallow braided } \\
\text { fluvial system }\end{array}$ \\
\hline $\begin{array}{l}\text { termination of extraglacial } \\
\text { lake (completely upfilled } \\
\text { with sandur sediments) } \\
\text { - lack of lacustrine base } \\
\text { level; } \\
\text { extensive meltwater dis- } \\
\text { charges; } \\
\text { highly unsteady hydrologi- } \\
\text { cal regime }\end{array}$ & $\begin{array}{l}\text { continuation of upstream- } \\
\text { controlled aggradation; } \\
\text { permanent increase of } \\
\text { sandur slope; } \\
\text { considerable increase of } \\
\text { flow energy; } \\
\text { accumulation of unit } 3\end{array}$ & $\begin{array}{l}\text { sandy-gravelly foreset } \\
\text { bars; } \\
\text { 3-D sand dunes in interbar } \\
\text { pools; washed-out dunes } \\
\text { and upper plane bed in } \\
\text { channel shoals }\end{array}$ & $\begin{array}{l}\text { middle sandur zone; } \\
\text { sand/gravel-bed river with } \\
\text { very low-sinuous channels } \\
\text { predominated by central } \\
\text { bars; } \\
\text { typical braided fluvial } \\
\text { system }\end{array}$ \\
\hline $\begin{array}{l}\text { stable lake level (western } \\
\text { meltwater inflow equal to } \\
\text { eastern outflow) }\end{array}$ & $\begin{array}{l}\text { sandur progradation into } \\
\text { the lake; } \\
\text { upstream-controlled aggra- } \\
\text { dation of sandur system; } \\
\text { onset of increasing sandur } \\
\text { slope; } \\
\text { increasing flow energy; } \\
\text { accumulation of unit } 2 \\
\end{array}$ & $\begin{array}{l}\text { sandy foreset bars in } \\
\text { straight channel segments, } \\
\text { 3-D dunes in interbar } \\
\text { pools; } \\
\text { sandy side bars in sinuous } \\
\text { channel segments }\end{array}$ & $\begin{array}{l}\text { middle-to-distal sandur } \\
\text { zone; } \\
\text { sand-bed, bedload-type } \\
\text { channels with central and } \\
\text { side bars; } \\
\text { fluvial system transitional } \\
\text { to braided pattern }\end{array}$ \\
\hline $\begin{array}{l}\text { rising level of extraglacial } \\
\text { lake; } \\
\text { extensive meltwater } \\
\text { discharge and sediment } \\
\text { transport during maximum } \\
\text { extent of ice-sheet margin }\end{array}$ & $\begin{array}{l}\text { downstream-controlled } \\
\text { aggradation of sandur } \\
\text { system; } \\
\text { decreasing slope of sandur; } \\
\text { low energy of channel } \\
\text { flows; } \\
\text { slight lateral erosion; } \\
\text { accumulation of unit } 1\end{array}$ & $\begin{array}{l}\text { deep flows in main chan- } \\
\text { nels of moderate sinuosity } \\
\text { and lateral migration - } \\
\text { formation of side bars; } \\
\text { shallow flows in sec- } \\
\text { ondary channels of low } \\
\text { sinuosity - predominance } \\
\text { of upper plane bed and } \\
\text { ripples (lack of bars and } \\
\text { large bedforms), frequent } \\
\text { abandoning (suspension } \\
\text { settling) during mean and } \\
\text { low stages }\end{array}$ & $\begin{array}{l}\text { anabranching fluvial } \\
\text { system of distal sandur } \\
\text { (few main, deep channels } \\
\text { coexisting with numerous } \\
\text { secondary, shallow chan- } \\
\text { nels); } \\
\text { anabranching fluvial } \\
\text { system } \\
\text { with anastomosed-like } \\
\text { pattern }\end{array}$ \\
\hline
\end{tabular}

Sinuosity and depth changes of the fluvial system were undoubtedly controlled by variations in the slope of the sandur surface (Table 2). The lake-level rise forced extensive aggradation in the distal sandur zone, with a decreasing slope of the sandur and an increase in channel sinuosity as a consequence. In contrast, even a slight but permanent increase in the sedimentary surface slope, related to enlarged aggradation on the proximal sandur during lake-level stabilization, caused an opposite fluvial reaction: reduction of the sinuosity. This evolution of the sandur fluvial system is consistent with the classic model of Leopold \& Wolman (1957), which was confirmed by numerous research- ers (among others Schumm, 1981; Ferguson, 1987): a slope increase forces river braiding, whereas a slope decrease results in a tendency to meandering.

\section{Conclusions}

It is possible that a sandur environment may be represented, under specific morphological conditions, by a low-energy, anabranching fluvial system. Deposits of such an atypical Pleistocene environment, quite different from that of a braided river, have been found in a foremountain zone of southern Poland. 
The most characteristic and interesting of this atypical sandur are the two lower units. Unit 1 contains mostly fine-grained sandy packages in which palaeochannels are developed. The ribbons represent two types of channel infills. In the main, deep, sinuous channels, the side bars and point bars (laterally accreted $S i$ beds) formed. In the secondary, shallow channels of low sinuosity, upper-stage plane beds (lithofacies Sh) dominated during flood stages, whereas ripples were formed by weak currents during stages of average discharge $(S r)$.

The presence of two palaeochannel types indicates that the sandur represents a fluvial system with an anabranching channel network. A number of sedimentological features (the relatively low energy of currents, the moderate sinuosity together with a low width-to-depth ratio of channels, and their limited lateral migration) suggests that this proglacial fluvial system formed an anastomosed river.

A genetic link of this channel pattern with specific environmental conditions is proposed. The outwash hydrology was mainly controlled by the base level of a lake which was dammed in a small valley sloping in opposite direction to the ice-sheet advance. The lake was fed by meltwaters, which were responsible for a continuous rise of its level. In this way, the slope of the outwash streams decreased, resulting in the development of an anastomosed-like pattern of channels, which is very rare and atypical of the glaciofluvial environment.

The evolution of the sandur resulted in a special morphology of the feeder fluvial system, reflected by the sinuosity and depth changes of its palaeochannels. During the first phase (rising base level of sandur), the proglacial channels were deep and highly sinuous. Afterwards (stable base level), both parameters decreased. The agent controlling the evolution of the fluvial system was the change in slope of the outwash plain: after an initial decrease of the slope, due to aggradation in the distal zone, the sedimentary surface steepened somewhat in response to aggradation on the proximal sandur.

\section{Acknowledgements}

Professional and valuable reviews by Piotr Weckwerth and Wojciech Wysota are gratefully acknowledged.

\section{References}

Aitken, J.F., 1998. Sedimentology of Late Devensian glaciofluvial outwash in the Don Valley, Grampian Region. Scottish Journal of Geology 34, 97-117.

Allen, J.R.L., 1965. A review of the origin and character of recent alluvial sediments. Sedimentology 5, 89-191.

Bluck, B.J., 1979. Structure of coarse grained braided stream alluvium. Transactions of the Royal Society of Edinburgh 70, 181-221.

Boothroyd, J.C. \& Ashley, G.M., 1975. Processes, bar morphology and sedimentary structures on braided outwash fans, Northeastern Gulf of Alaska. [In:] Jopling, A.V. \& McDonald, B. . (Eds), Glaciofluvial and glaciolacustrine sedimentation. Society of Economic Paleontologists and Mineralogists, Special Publication 23, 193-222.

Boothroyd, J.C. \& Nummedal, D., 1978. Proglacial braided outwash: a model for humid alluvial-fan deposits. [In:] Miall, A.D. (Ed.), Fluvial Sedimentology. Canadian Society of Petroleum Geologists Memoir 5, 641-668.

Bridge, J.S. \& Lunt, I.A., 2006. Depositional models of braided rivers. [In:] Sambrook Smith, G.H., Best, J.L., Bristow, C.S. \& Petts, G.E. (Eds), Braided rivers: process, deposits, ecology and management. International Association of Sedimentologists, Special Publication 36, 11-50.

Bridge, J.S., Collier, R. \& Alexander, J., 1998. Large-scale structure of Calamus deposits (Nebraska, USA) revealed using ground-penetrating radar. Sedimentology 45, 977-986.

Bristow, C.S., 1993. Sedimentary structures exposed in bar tops in the Brahmaputra River, Bangladesh. [In] Best, J.L. \& Bristow, C.S. (Eds), Braided rivers. Geological Society, Special Publication 75, 277-289.

Church, M., 1972. Baffin Island sandurs: a study of Arctic fluvial processes. Bulletin of the Geological Survey of Canada 216, 1-208.

Dawson, M.R. \& Bryant, I.D., 1987. Three-dimensional facies geometry in Pleistocene outwash sediments, Worcestershire, U.K. [In:] Ethridge, F.G. (Ed.), Recent developments in fluvial sedimentology. Society of Economic Paleontologists and Mineralogists Special Publication 39, 191-196.

Doktor, M. \& Gradziński, R., 1985. Alluvial depositional environment of coal-bearing "Mudstone Series", Upper Carboniferous, Upper Silesian Coal Basin. Studia Geologica Polonica 82, 1-67. (in Polish, with English summary) 
Ferguson, R.J., 1984. The threshold between meandering and braiding. [In] Smith, K.V. H. (Ed.), Proceedings of the 1st International Conference on Hydraulic Design. Springer, Berlin, 6.15-6.29.

Ferguson, R.J., 1987. Hydraulic and sedimentary controls of channel pattern. [In:] Richards, K.S. (Ed.): River channels: environment and process. Institute of British Geographers Special Publication (Blackwell, Oxford), 18, 125-158.

Fraser, G.S., 1993. Sedimentation in an interlobate outwash stream. Sedimentary Geology 83, 53-70.

Fraser, G.S. \& Cobb, J.C., 1982. Late Wisconsinan proglacial sedimentation along the West Chicago moraine in NE Illinois. Journal of Sedimentary Petrology 52, 473491.

Gibling, M.R. \& Rust, B.R., 1987. Evolution of a mud-rich meander belt in the Carboniferous Morien Group, Nova Scotia, Canada. Bulletin of Canadian Petroleum Geologists 35, 24-33.

Gibling, M.R., Nanson, G.C. \& Maroulis, J.C., 1998. Anastomosing river sedimentation in the Channel Country of central Australia. Sedimentology 45, 595-619.

Gradziński, R., 1970. Sedimentation of dinosaur-bearing Upper Cretaceous deposits of the Nemegt Basin, Gobi Desert. Palaeontologia Polonica 21, 147-229.

Graham, J.R., 1981. Fluvial sedimentation in the Lower Carboniferous of Clew Bay, County Mayo, Ireland. Sedimentary Geology 30, 195-211.

Haisig, J. \& Wilanowski, S., 1999. Detailed geological map of Poland 1:50 000, Tychy sheet. Polish Geological Institute, Warszawa.

Karaś-Brzozowska, C., 1963. Limit of the Middle-Polish (Saale) glaciation in the Raciborz Basin. Przeglad Geograficzny 35, 431-447. (in Polish, with English summary).

Kirschbaum, M.A. \& McCabe, P.J., 1992. Controls on the accumulation of coal and on development of anastomosed fluvial systems in the Cretaceous Dakota Fm. of S Utah. Sedimentology 39, 581-598.

Klimek, K., 1972. Present-day fluvial processes and relief of the Skeidararsandur plain, Iceland. Prace Geograficzne, Polska Akademia Nauk 94, 1-139. (in Polish, with English summary)

Klimek, K. \& Starkel, L., 1972. Kotliny Podkarpackie. [In:] Klimaszewski, M. (Ed.), Geomorfologia Polski, vol 1. PWN, Warszawa, 117-138.

Kotlicka, G.N. \& Kotlicki, S., 1979. Geological map of Poland 1:200 000, Gliwice A sheet. Polish Geological Institute, Warszawa.

Krigström, A., 1962. Geomorphological studies of sandur plains and their braided rivers in Iceland. Geografiska Annaler 44, 328-346.

Krzyszkowski, D., 1991. Saalian sediments of the Bełchatów outcrop, central Poland. Boreas 20: 29-46.

Leopold, L.B. \& Wolman, M.G., 1957. River channel patterns: braided, meandering and straight. U.S. Geological Survey Professional Paper, 282A, 1-85.

Lewandowski, J., 1982. Extent of ice sheet of MiddlePolish glaciation in the Silesian Upland. Biuletyn Instytutu Geologicznego 337, 115-142. (in Polish, with English summary)
Lewandowski, J., 1996. The main factors of Neogene and Quaternary morphogenetic evolution of the SilesianCracow region, S Poland. Acta Geographica Lodziensia 71, 131-148. (in Polish, with English summary)

Lunt, I.A., Bridge, J.S. \& Tye, R.S., 2004. A quantitative, three-dimensional depositional model of gravelly braided rivers. Sedimentology 51, 377-414.

Makaske, B., 1998. Anastomosing rivers. Forms, processes and sediments. Nederlandse eografische Studies, 249, 285 pp.

Makaske, B., 2001. Anastomosing rivers: a review of their classification, origin and sedimentary products. EarthScience Reviews 53, 149-196.

Makaske, B. \& Nap, R.L., 1995. A transition from a braided to a meandering channel facies, showing inclined heterolithic stratification (Late Weichselian, central Netherlands). Geologie en Mijnbouw 74, 13-20.

Marren, P.M., 2005. Magnitude and frequency in proglacial rivers: a geomorphological and sedimentological perspective. Earth-Science Reviews 70, 203-251.

McCarthy, T.S., Stanistreet, I.G. \& Cairncross, B., 1991. The sedimentary dynamics of active fluvial channels on the Okavango Fan, Botswana. Sedimentology 38, 471-487.

Miall, A.D., 1978. Lithofacies types and vertical profile models in braided rivers: A summary. [In:] Miall, A.D. (Ed.), Fluvial sedimentology. Canadian Society of Petroleum Geologists Memoir 5, 597-604.

Nanson, G.C. \& Knighton, A.D., 1996. Anabranching rivers: their cause, character and classification. Earth Surface Processes and Landforms 21, 217-239.

Olsen, H. \& Andreasen, F., 1995. Sedimentology and ground-penetrating radar characteristics of a Pleistocene sandur deposits. Sedimentary Geology 99, 1-15.

Perez-Arlucea, M., Mack, G. \& Leeder, M., 2000. Reconstructing the ancestral (Plio-Pleistocene) Rio Grande in its active tectonic setting, S Rio Grande rift, New Mexico, USA. Sedimentology 47, 701-720.

Rust, B.R., 1975. Fabric and structure in glaciofluvial gravels. [In:] Jopling, A.V. \& McDonald, B.C. (Eds), Glaciofluvial and glaciolacustrine sedimentation. Society of Economic Paleontologists and Mineralogists Special Publication 23, 238-248.

Rust, B.R., 1978. Depositional models for braided alluvium. [In:] Miall A.D. (Ed.), Fluvial sedimentology. Canadian Society of Petroleum Geologists Memoir 5, 605-625.

Rust, B.R. \& Legun, A.S., 1983. Modern anastomosingfluvial deposits in arid central Australia, and a Carboniferous analogue in New Brunswick, Canada. [In:] Collinson, J.D. \& Lewin, J. (Eds), Modern and ancient fluvial systems. International Association of Sedimentologists Special Publication 6, 385-392.

Salamon, T., 2009. Origin of Pleistocene outwash plains in various topographic settings, southern Poland. Boreas $38,362-378$.

Salamon, T. \& Wilanowski, S., 2003. Glacimarginalna depozycja osadów w północnej części Kotliny Oświęcimskiej [Glaciomarginal deposition in the $\mathrm{N}$ part of the Oświęcim Basin]. [In:] Plejstocen Kotliny Raciborsko-Oświęcimskiej na tle struktur morfotektonicznych pod- 
toża czwartorzędu. X Konferencja "Stratygrafia Plejstocenu Polski" Rudy 2003, 137-142.

Santos, M.L. \& Stevaux, J.C., 2000. Facies and architectural analysis of channel sandy macroforms in the upper Parana river. Quaternary International 72, 87-94.

Schumm, S.A., 1981. Evolution and response of the fluvial system, sedimentologic implications. [In:] Ethridge, F.G. \& Flores, R.M. (Eds), Non-marine depositional environments: models for exploration. Society of Economic Paleontologists and Mineralogists Special Publication 31, 19-29.

Shuster, M.W. \& Steidtmann, J.R., 1987. Fluvial-sandstone architecture and thrust-induced subsidence, N Green River Basin, Wyoming. [In:] Ethridge, F.G., Flores, R.M. \& Harvey, M.D. (Eds), Recent developments in fluvial sedimentology. Society of Economic Paleontologists and Mineralogists Special Publication 39, 279-285.

Singh, I.B., 1977. Bedding structures in a channel sand bar of the Ganga River near Allahabad, Uttar Pradesh, India. Journal of Sedimentary Petrology 47, 747-752.

Smith, D.G., 1987. Meandering river point bar lithofacies models: modern and ancient examples compared. [In:] Ethridge, F.G., Flores R.M. \& Harvey M.D. (Eds), Recent developments in fluvial sedimentology. Society of Economic Paleontologists and Mineralogists Special Publication 39, 83-91.

Smith, D.G., 1983. Anastomosed fluvial deposits: modern examples from western Canada. [In:] Collinson, J.D. \& Lewin, J. (Eds), Modern and ancient fluvial systems. International Association of Sedimentologists Special Publication 6, 155-168.

Smith, N.D., 1970. The braided stream depositional environment: comparison of the Platte River with some
Silurian clastic rocks, north-central Appalachians. Geological Society of America Bulletin 81, 2993-3014.

Smith, N.D., McCarthy, T.S., Ellery, W.N., Merry, C.L. \& Rüther, H., 1997. Avulsion and anastomosis on the panhandle region of the Okavango Fan, Botswana. Geomorphology 20, 49-65.

Teisseyre, A.K., 1992. Anastomosing rivers - processes and sedimentary models. Przeglad Geologiczny,40, 241-248. (in Polish, with English summary)

Tooth, S. \& Nanson, G.C., 1999. Anabranching rivers on the Northern Plains of arid central Australia. Geomorphology 29, 211-233.

Törnqvist, T.E., Van Ree, M.H.M. \& Faessen, E.L.J.H., 1993. Longitudinal facies architectural changes of a Middle Holocene anastomosing distributary system (Rhine-Meuse delta, central Netherlands). Sedimentary Geology 85, 203-219.

Wende, R. \& Nanson, G.C., 1998. Anabranching rivers: ridge-form alluvial channels in tropical $\mathrm{N}$ Australia. Geomorphology 22, 205-224.

Wysota, W., Lankauf, K.R., Molewski, P. \& Szmańda, J., 1996. Sedimentology of the interstadial fluvial series (Rzęczkowo) of the Vistulian Glaciation exposed in the SW margin of the Chełmno Moraine Plateau. Acta Universitatis Nicolai Copernici, Geografia 28, 39-63. (in Polish with English summary)

Zieliński, T. \& Van Loon, A. J., 2003. Pleistocene sandur deposits represent braidplains, not alluvial fans. Boreas 32, 590-611.

Manuscript received 21 January 2010; revision accepted 19 April 2010. 